\title{
Changes in biotic and abiotic processes following mangrove clearing
}

\author{
Elise Granek ${ }^{\mathrm{a}, *}$, Benjamin I. Ruttenberg ${ }^{\mathrm{b}, 1}$ \\ a Department of Zoology, Oregon State University, Corvallis, OR, USA \\ ${ }^{\mathrm{b}}$ Department of Ecology, Evolution and Marine Biology, University of California, Santa Barbara, CA 93106, USA
}

\begin{abstract}
A B S T R A C T
Mangrove forests, important tropical coastal habitats, are in decline worldwide primarily due to removal by humans. Changes to mangrove systems can alter ecosystem properties through direct effects on abiotic factors such as temperature, light and nutrient supply or through changes in biotic factors such as primary productivity or species composition. Despite the importance of mangroves as transitional habitats between land and sea, little research has examined changes that occur when they are cleared. We examined changes in a number of biotic and abiotic factors following the anthropogenic removal of red mangroves (Rhizophora mangle) in the Panamanian Caribbean, including algal biomass, algal diversity, algal grazing rates, light penetration, temperature, sedimentation rates and sediment organic content. In this first study examining multiple ecosystem-level effects of mangrove disturbance, we found that areas cleared of mangroves had higher algal biomass and richness than intact mangrove areas. This increase in algal biomass and richness was likely due to changes in abiotic factors (e.g. light intensity, temperature), but not biotic factors (fish herbivory). Additionally the algal and cyanobacterial genera dominating mangrove-cleared areas were rare in intact mangroves and included a number of genera that compete with coral for space on reefs. Interestingly, sedimentation rates did not differ between intact and cleared areas, but the sediments that accumulated in intact mangroves had higher organic content. These findings are the first to demonstrate that anthropogenic clearing of mangroves changes multiple biotic and abiotic processes in mangrove forests and that some of these changes may influence adjacent habitats such as coral reefs and seagrass beds. Additional research is needed to further explore the community and ecosystem-level effects of mangrove clearing and their influence on adjacent habitats, but it is clear that mangrove conservation is an important aspect of managing tropical coastal systems.
\end{abstract}

\section{Introduction}

Human disturbance has consequences for ecosystem functioning via changes to physical or abiotic conditions (e.g. light, temperature, nutrients) as well as species interactions or biotic factors (Levin et al., 2006). The relative importance of these factors depends on the frequency, intensity, and type of disturbance, and on the resilience of the ecosystem (Power et al., 1996; Hughes et al., 2005). However, little work on this topic has been conducted in coastal interface habitats, such as salt marshes and mangrove forests (but see Kelaher et al., 1998; Walters, 2005; Granek and Frasier, 2007; Whitcraft and Levin, 2007; Alongi and de Carvalho, 2008). Given that anthropogenic impacts are likely to continue to

\footnotetext{
* Corresponding author at current address: Portland State University, PO Box 751, Environmental Sciences \& Management, Portland, OR 97207, USA

E-mail address: graneke@pdx.edu (E. Granek).

1 Current address: US National Park Service, SFCN, 18001 Old Cutler Road, Ste 419, Palmetto Bay, FL 33157, USA
}

increase in coastal zones around the world, it is important to better understand how loss or modification of these habitats may affect ecosystem functioning.

In the tropics, coastal marine ecosystems are increasingly impacted by human activities. This is particularly true for mangroves which are considered threatened globally (UNEP, 1995; Wilkie and Fortuna, 2003). The area occupied by mangrove forests has declined worldwide by more than $35 \%$, and half of this loss has occurred over the past 30 years, primarily due to human disturbance (Field et al., 1998). Loss of mangrove forests is caused by a variety of factors, including cutting and clearing for lumber and firewood, clearing and filling for agriculture and coastal development, and clearing and replacement of mangrove habitat with aquaculture (UNEP, 1995; Ogden, 2001; Valiela et al., 2001; Wilkie and Fortuna, 2003). In many places, mangrove loss is occurring without regard for the role of mangroves in the functioning of coastal ecosystems (e.g. Alongi, 2008). Mangroves may help protect neighboring coral reefs and seagrass beds from terrestrial runoff (UNEP, 1995), shelter coastlines from storm damage (Naylor and 
Drew, 1998; Dahdouh-Guebas et al., 2005; Granek and Ruttenberg, 2007), and serve as nursery and feeding grounds for a variety of species of invertebrates and fishes (Nagelkerken et al., 2000, 2001; Mumby et al., 2004). Therefore, mangroves may play important roles in the functioning of other coastal ecosystems in the tropics.

However, it is still largely unknown how mangrove loss may alter ecosystem function in mangrove forests themselves. In other coastal habitats such as salt marshes, removal of vegetation can result in harsher abiotic conditions in soils and sediments and significant shifts in the structure of associated benthic communities (Whitcraft and Levin, 2007). Similarly, loss of mangrove forests may alter the habitats and communities via biotic and abiotic pathways. For example, growth of benthic algae may increase as a result of greater light intensity, nutrient availability, and frequency of high temperature events (but see Gwyther and Fairweather, 2002). Sedimentation rates and organic content of sediments may change with mangrove clearing (e.g. Alongi and de Carvalho, 2008), which may in turn impact associated mangrove communities and adjacent habitats. Loss of mangroves will also greatly reduce habitat complexity and is likely to affect community structure of many species, including algae, herbivores, and other fauna (Eston et al., 1992; Dye, 2006).

In this study, we test the hypothesis that a number of measures of ecosystem function in mangrove forests are significantly altered when mangroves are cleared. The abiotic factors we examine include sedimentation rate, organic content of sediments, temperature, and light intensity. Because many of these factors may interact with biotic factors (e.g. herbivory, competition) to structure algal communities, we examine changes in benthic algal biomass and community structure in the presence and absence of herbivory. Our results provide evidence that mangrove clearing affects a number of these parameters through both direct abiotic and indirect biotic pathways. Therefore, it is important to improve mangrove conservation since their removal may have effects throughout mangrove ecosystems and on adjacent habitats.

\section{Materials and methods}

\subsection{Study area}

This study was conducted in Almirante Bay, Bocas del Toro Province, Panama (Fig. 1). Within the study region, sites that met the following criteria were selected for this study: (1) at least $100 \mathrm{~m}$ long stretch of cleared red mangroves adjacent to stretches of at least $100 \mathrm{~m}$ of intact red mangroves to provide sufficient cleared areas for comparison; (2) fringing or patch reefs within $100 \mathrm{~m}$ of the seaward mangrove edge to allow us to conduct additional studies on connections between mangroves and reefs; (3) $>2 \mathrm{~km}$ from major human development or construction projects to exclude potential spurious anthropogenic influences. Five sites met these criteria, and were located within $20 \mathrm{~km}$ of each other (Fig. 1), with three on Isla Colon (from northwest to southeast: Red Point, Punta Caracole North, and Punta Caracole South), one on Isla Pastores (Pastores), and one on the mainland south of Almirante (Punta Gallinazo). The coastline at all sites was characterized by Rhizophora mangle trees in fully marine areas (tidal range in Almirante Bay, Panama is $<65 \mathrm{~cm}$ ), except where stands had been cleared for agriculture, construction, or viewsheds. Mangrovecleared areas ranged from 100 to $300 \mathrm{~m}$ in length along the shore, were generally cut to a few centimeters above the substrate surface, and included the entire width of the mangrove area (i.e. landward to seaward). On Isla Colon, mangrove clearing occurred approximately 8 years prior to this study (historically cleared sites) and mangrove-cleared areas were characterized by submerged decaying prop roots on the substrate with significant macroalgal growth inshore and the seagrass Thalassia testudinum growth further from shore. Little three-dimensional structure remained in these mangrove-cleared areas as cleared mangrove material had been removed from the shoreline and shallow subtidal. At Pastores and Gallinazo (recently cleared sites), clearing occurred during the 12 months prior to the study and disturbed areas retained dead, exposed mangrove stands attached to the substrate, covered subtidally with algae, and fringed by seagrass along the seaward edge. At Pastores and Gallinazo, subtidal root structure in cleared areas was substantially greater leading to subtidal structure intermediate between intact mangroves and the three Isla Colon mangrove cleared areas. Intact mangrove areas were characterized by submerged prop roots colonized by oysters, sponges, sporadic small live corals, and infrequently epibiotic algae with occasional nonforested channels between trees. In intact areas at the five sites examined in this study, epibiotic algal cover on mangrove prop roots, trunks and soft sediment substrate was extremely low; cyanobacterial mats on the substratum were sporadic. Overall, the proportion of hard surfaces (mangrove roots, dead coral, etc.) within the soft bottom substrate was comparable between cleared and intact mangrove areas due to the cut prop roots protruding a few centimeters above the substrate.

\subsection{Algal biomass and richness}

Algal biomass was quantified at the five sites along a total of 40 20-m long transects. Experimental design included two subhabitats (mangrove edge and mangrove center) in each of two 'treatments' (mangrove-intact and mangrove-cleared). There were two replicates in each subhabitat by treatment combination and these ran parallel to shore, for a total of 8 replicates at each site. Transects in subhabitats were generally separated by $25 \mathrm{~m}$, subhabitats (edge and center of mangroves) were generally separated by $10 \mathrm{~m}$, and treatments (cleared and intact mangroves) were generally separated by $50 \mathrm{~m}$. Each transect was delineated by a $20-\mathrm{m}$ long by 1 -mm thick yellow nylon cord located approximately $30 \mathrm{~cm}$ above the substratum, anchored using PVC stakes, run among the seaward-edge prop roots of intact mangroves or where mangroves had been in the cleared areas, and below MLLW. Because much of the substrate along transects is not solid (i.e. detritus/mud/sand with macroalgae and cyanobacteria), this cord (simulating remaining root structure or hard substrata including dead coral) provided substrate for algal growth. Algae readily attached to the rough surface of the nylon cord, allowing for easy sampling (Buck and Buchholz, 2004). The nylon cord was used as a standard surface to minimize differences in substrate heterogeneity but was not intended to exactly mimic the natural substrate or the community thereon. We averaged the number of algal taxa per line in each transect.

Samples were taken by removing six randomly selected $15-\mathrm{cm}$ long segments from the line 9 weeks after the cord was deployed. These segments (subsamples) were averaged to derive a transect mean. Sample lines were rinsed to remove detritus and sand, and algal taxa were identified under a dissecting scope based on Littler and Littler (2000). We used genera as a proxy for functional groups, since identification to species is nearly impossible in the field for many groups. Since ecological studies involving marine algae often take a functional-form approach (Steneck and Dethier, 1994), we quantified taxonomic diversity as the number of genera. After identification, all algal and cyanobacterial biomass was scraped off the line, dried at $60^{\circ} \mathrm{C}$, and weighed to determine biomass.

\subsection{Herbivory}

To quantify the influence of herbivorous fishes on differences in algal biomass between intact and cleared areas, herbivore exclusion cages were deployed at Red Point, Punta Caracole North, and 


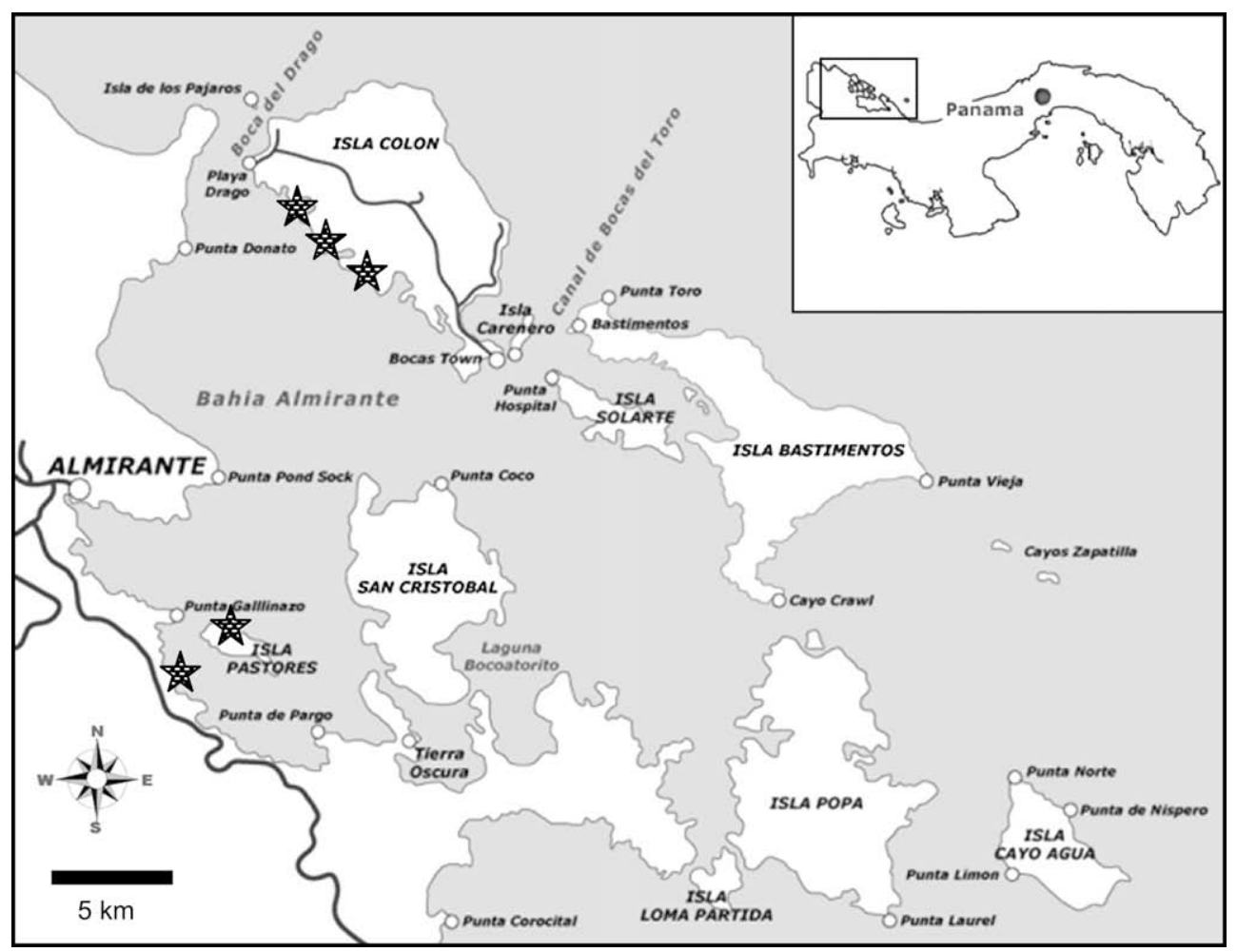

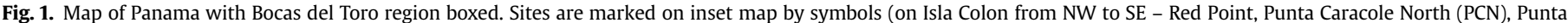
Caracole South (PCS); Pastores, on Isla Pastores and Gallinazo, south of Punta Gallinazo).

Pastores. We constructed herbivore exclusion cages of Naltex tubular diamond mesh bag $(1.4 \mathrm{~cm}$ mesh) stretched to $\sim 20 \mathrm{~cm}$ in length and held open with three rings of $0.75 \mathrm{~cm} \times 15 \mathrm{~cm}$ PVC rings; the ends were covered with Vexar L-30 mesh (Redden Net Company Inc., Port Coquitlam, BC, Canada) attached with cable ties. Cage controls were similar but had two 6-cm diameter holes cut in the mesh on each side of the cage. The cages were threaded onto the lines when the experiment was deployed. This design excluded herbivorous fishes from the 20 -cm stretch of cord surrounded by the cage. Herbivorous stocky ceriths (the gastropod Cerithium litteratum) occasionally entered the cages but were removed during bi-weekly monitoring visits, and since no other herbivores were seen in the cages, we are confident that the cages excluded the dominant herbivores, fishes. Fishing pressure is relatively high in the Bocas del Toro region, and herbivorous fishes are taken in the fishery (Dominici-Arosemena and Wolff, 2005). However, herbivorous fishes are common both in the mangroves and on reefs, and are frequently seen grazing in and near mangroves (E. Granek, unpublished data). The line in cages and cage controls was sampled after 9 weeks as described above. The shading effect of cages and cage controls was far greater than the impact of herbivory on open lines. Therefore, we quantified herbivory as the difference in algal biomass between cages (closed to herbivory) and cage controls (open to herbivory).

\subsection{Water temperature and light variation}

Two i-button data loggers (i-button Temperature Loggers DS1921G, Maxim Direct, Dallas, TX) were deployed along each transect line at the beginning of the experiment and programmed to measure temperature hourly. We calculated the proportion of high temperature events exceeding $30.5^{\circ} \mathrm{C}$ (selected because local reef temperatures rarely exceed $30^{\circ} \mathrm{C}$ (E. Granek, unpublished data) and $30^{\circ} \mathrm{C}$ is often considered a bleaching threshold for corals (Hoegh-Goldberg and Salvat, 1995; Brown, 1997)).

Light intensity was measured using a Li-cor Underwater Quantum Sensor (LI-192) and a Li-cor Atmospheric Quantum Sensor (LI-190) to standardize light measurements to ambient light conditions with a Li-cor data logger (LI-1400). Four light readings were taken per point at five points along each transect on a clear sunny day. Measurements were standardized to ambient light readings and averaged to determine mean light intensity per transect line $\left(\mu \mathrm{mol} \mathrm{s}{ }^{-1} \mathrm{~m}^{-2}\right.$ ).

\subsection{Sedimentation}

Sedimentation rates, or the delivery rate of sediment from the water column, were measured using PVC tube traps; tubes were $3.81 \mathrm{~cm}$ diameter $\times 19.05 \mathrm{~cm}$, capped at the bottom and anchored to rebar stakes with the bottoms in contact with the benthos (Hargrave and Burns, 1979; Bothner et al., 2006). Tube traps at mangrove edge areas remained submerged, while those in the mangrove center (landward) were exposed during the lowest tide of the month. Three sediment traps were deployed on each transect line for approximately 8 weeks. Sediment was removed from each trap and dried at $60^{\circ} \mathrm{C}$ until no further weight loss occurred. We then calculated mean final dry weight of sediment per transect.

\subsection{Organic content}

Sediment samples were homogenized by transferring samples into glass bottles containing 4-7 stainless steel grinding rods. These were tumbled on a roller-grinder machine (Butler et al., 2004) until samples were the consistency of talcum powder. Following the protocol described in Nelson and Sommers (1996), $2 \pm 0.5 \mathrm{~g}$ of homogenized sample were then transferred to a pre-weighed crucible, heated at $105{ }^{\circ} \mathrm{C}$, reweighed to determine dry weight of 
the sample, and combusted in a Muffle furnace at $400{ }^{\circ} \mathrm{C}$. Postcombustion weight was used to calculate percent organic content per sediment sample by using loss on ignition (LOI) as a proxy for organic matter (LOI \% $=\left[\right.$ (weight at $105^{\circ} \mathrm{C}$ - weight at $\left.400{ }^{\circ} \mathrm{C}\right) /$ weight at $\left.\left.\left.105^{\circ} \mathrm{C}\right) \times 400\right]\right)$.

\subsection{Statistical analysis}

For each analysis, the residuals were examined for normality and variance. To improve normality, algal biomass and high temperature events were $\ln (x+1)$ transformed; sedimentation and organic matter data were square-root transformed.

We used a blocked design and mixed effects ANOVAs to analyze the algal growth experiments, using treatment (cleared or intact mangrove areas) and habitat (edge or center of mangrove areas) as fixed effects and site as a random effect, and including all interactions. We conducted two separate analyses, one using algal biomass and another using algal generic diversity as the response variable (Table 1). We used a similar design to examine the effects of herbivory, including the addition of cage type (partially open [cage

Table 1

Results from ANOVAs, including all factors and 2nd order interactions. All effects are fixed unless noted as random. Treatment refers to cleared vs. intact mangroves; habitat refers to center vs. edge of the mangroves. $p$-values $<0.05$ are shown in bold type

\begin{tabular}{|c|c|c|c|c|c|}
\hline Experiment/analysis & Factor & MS & df & $F$ & $p$ \\
\hline \multirow[t]{7}{*}{ Algal biomass } & Treatment & 4.25 & 1 & 59.9 & $<0.0001$ \\
\hline & Site (random) & 1.67 & 4 & 1.56 & 0.22 \\
\hline & Treatment $\times$ site & 2.69 & 4 & 2.50 & 0.069 \\
\hline & Habitat & 0.18 & 1 & 0.17 & 0.69 \\
\hline & Treatment $\times$ habitat & 0.04 & 1 & 0.037 & 0.85 \\
\hline & Site $\times$ habitat & 1.18 & 4 & 1.10 & 0.38 \\
\hline & Error & 1.08 & 24 & & \\
\hline \multirow[t]{7}{*}{ Algal diversity } & Treatment & 18.0 & 1 & 1.13 & 0.35 \\
\hline & Site (random) & 15.99 & 4 & 18.8 & $<0.0001$ \\
\hline & Treatment $\times$ site & 3.08 & 4 & 3.62 & 0.020 \\
\hline & Habitat & 16.98 & 1 & 19.97 & 0.0002 \\
\hline & Treatment $\times$ habitat & 2.37 & 1 & 2.78 & 0.11 \\
\hline & Site $\times$ habitat & 3.43 & 4 & 4.03 & 0.013 \\
\hline & Error & 0.85 & 23 & & \\
\hline \multirow[t]{11}{*}{ Herbivore exclusion } & Treatment & 17.10 & 1 & 21.1 & 0.0001 \\
\hline & Site (random) & 0.062 & 2 & 0.076 & 0.93 \\
\hline & Treatment $\times$ site & 0.85 & 2 & 1.05 & 0.36 \\
\hline & Habitat & 0.57 & 1 & 0.70 & 0.41 \\
\hline & Treatment $\times$ habitat & 2.49 & 1 & 3.07 & 0.092 \\
\hline & Site $\times$ habitat & 3.27 & 2 & 4.03 & 0.030 \\
\hline & Cage type & 10.81 & 1 & 13.3 & 0.0012 \\
\hline & Treatment $\times$ age type & 0.0019 & 1 & 0.0023 & 0.96 \\
\hline & Site $\times$ cage type & 0.65 & 2 & 0.80 & 0.46 \\
\hline & Habitat $x$ cage type & 0.59 & 1 & 0.72 & 0.40 \\
\hline & Error & 0.81 & 25 & & \\
\hline \multirow[t]{7}{*}{ Light intensity } & Treatment & 24.57 & 1 & 136.7 & $<0.0001$ \\
\hline & Site (random) & 0.20 & 4 & 1.09 & 0.38 \\
\hline & Treatment $\times$ site & 0.22 & 4 & 1.20 & 0.34 \\
\hline & Habitat & 0.38 & 1 & 2.10 & 0.16 \\
\hline & Treatment $\times$ habitat & 0.24 & 1 & 1.32 & 0.26 \\
\hline & Site $\times$ habitat & 0.13 & 4 & 0.74 & 0.57 \\
\hline & Error & 0.18 & 24 & & \\
\hline \multirow[t]{7}{*}{ Sediment trap } & Treatment & 0.46 & 1 & 0.19 & 0.68 \\
\hline & Site (random) & 2.37 & 4 & 2.83 & 0.048 \\
\hline & Treatment $\times$ site & 6.01 & 4 & 7.17 & 0.001 \\
\hline & Habitat & 0.04 & 1 & 0.047 & 0.83 \\
\hline & Treatment $\times$ habitat & 2.07 & 1 & 2.47 & 0.13 \\
\hline & Site $\times$ habitat & 0.72 & 4 & 0.86 & 0.51 \\
\hline & Error & 0.84 & 23 & & \\
\hline \multirow[t]{7}{*}{ Organic matter } & Treatment & 11.10 & 1 & 10.68 & 0.031 \\
\hline & Site (random) & 1.04 & 4 & 3.26 & 0.030 \\
\hline & Treatment $\times$ site & 1.16 & 4 & 3.62 & 0.020 \\
\hline & Habitat & 11.59 & 1 & 36.32 & $<0.0001$ \\
\hline & Treatment $\times$ habitat & 2.21 & 1 & 6.91 & 0.015 \\
\hline & Site $\times$ habitat & 0.28 & 4 & 0.88 & 0.49 \\
\hline & Error & 0.32 & 23 & & \\
\hline
\end{tabular}

control] or closed [caged]) as a fixed factor. We used the statistical model from the algal growth experiments to test the effects of clearing on light penetration, sedimentation, and organic matter (including treatment and habitat as fixed factors, site as a random factor, and the interactions). For temperature data, we calculated the proportion of high temperature events $\left(>30.5^{\circ} \mathrm{C}\right)$, and pooled within treatment and site (since temperature data within each treatment $\times$ site combination are likely not truly independent).

\section{Results}

\subsection{Algal biomass}

Algal biomass was significantly higher in cleared areas than in intact areas $(p<0.001$, Fig. 2, Table 1$)$, but there was also a marginally significant treatment $\times$ site interaction $(p=0.069)$, suggesting that the magnitude of the effect varied among sites (Fig. 2). There were no habitat differences (center vs. edge of mangroves), among sites, or any first order interactions among these factors (Table 1).

\subsection{Algal communities}

There were no significant effects of treatment on algal generic richness, but there were highly significant differences among sites $(p<0.0001$, Fig. 3a, Table 1$)$. The proportion of line segments with $>50 \%$ cover of at least one algal or cyanobacterial taxon (referred to hereafter as dominant) was greater in cleared areas than in intact areas (ANOVA, $F=29.2 ; \mathrm{df}=1,29 ; p<0.001$ ). Three cyanobacterial genera dominated transects in cleared areas whereas two dominated in intact areas (Fig. 3b). In cleared areas, 14 algal genera were dominant, whereas in intact areas, only seven genera were dominant. Lyngbya sp. and Dictyota sp. were most common overall. Number of algal taxa per line was averaged for each transect and for the replicate transects in each area and mangrove condition to determine differences in algal taxon diversity in intact vs. cleared areas.

\subsection{Herbivory}

There was a strong effect of fish herbivory in both the cleared and intact areas, and this effect was consistent between treatments (cage effect: $p=0.0012$; effect of clearing (treatment effect): $p=0.0001$; cage $\times$ treatment interaction: NS; Fig. 4, Table 1 ). There were no main effects of site or habitat (center vs. edge of mangroves), but there was a weak but significant site $\times$ habitat interaction $(p=0.03$, Table 1$)$.

\subsection{Abiotic factors}

We found major effects of treatment on light and temperature (Fig. 5a,b). As expected, light intensity was greater in cleared than in intact mangrove areas ( $p<0.0001$; Fig. 5a, Table 1$)$, and there were no other significant effects or interactions. The number of high temperature events was also greater in cleared than in intact areas (paired $t$-test, $=4.88, \mathrm{df}=4, p=0.008$; Fig. $5 \mathrm{~b}$ ). There was no significant effect of clearing on sedimentation rate, but there were significant site and site $\times$ treatment effects (treatment, NS; site, $p=0.048$; site $\times$ treatment, $p=0.001$; Fig. $5 c$, Table 1 ). Finally, organic content of sediments was higher in intact vs. cleared areas $(p=0.031$; Fig. $5 d)$, but there were also site effects $(p=0.03)$, habitat effects $(p<0.0001)$, treatment $\times$ site interactions $(p=0.02)$ and treatment $\times$ habitat interactions $(p=0.015)$. 


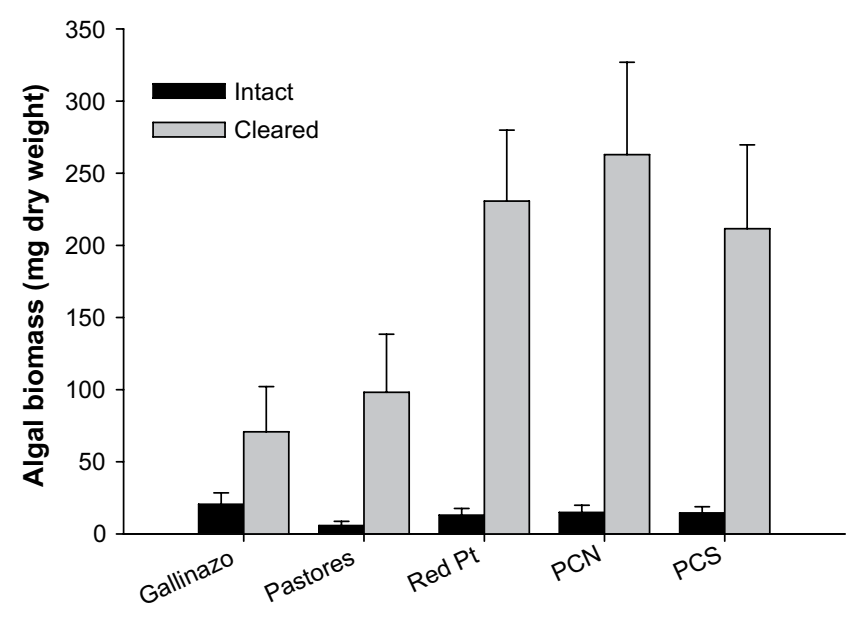

Fig. 2. Mean algal biomass, by site and treatment (cleared vs. intact mangroves). Error bars represent $\pm 1 \mathrm{SE}$.

\section{Discussion}

Our results demonstrate that a number of ecosystem processes are significantly modified by clearing mangrove forests. Algal biomass, light penetration, and high temperature events increase while organic content of sediments decreases in areas that have been cleared of mangroves. In addition, algal community composition changed between cleared and intact mangrove areas, and generic-level diversity of algal communities actually increased in cleared areas. Interestingly, while consumption of algae by herbivorous fishes was greater in mangrove-cleared areas, the increased levels of herbivory were insufficient to compensate for the increased levels of algal growth, resulting in similar levels of algal biomass between herbivore exposed areas in cleared mangroves and herbivore excluded areas in intact mangroves (Fig. 4). These patterns suggest that disturbance to mangrove structure increased the dominance of macroalgae via shifts in abiotic (e.g. light, temperature) rather than biotic (e.g. herbivory) factors.

Areas with intact mangrove cover had much lower levels of algal biomass than areas from which mangroves were cleared, both on our experimental surface and natural substrates at each site (Fig. 3; E. Granek, personal observation). In this system, light may be the primary driver of algal abundance and community structure, and not surprisingly light penetration was highly significantly greater in areas cleared of mangroves than areas with intact mangroves (Fig. 5a). Light can limit algal and cyanobacterial growth (Irving and Connell, 2002; Pang and Luning, 2004), and additional observations suggest that light levels and algal biomass were much higher below canopy gaps in intact mangrove stands than in the shaded areas below the canopy (E. Granek, personal observation).

Light appears to be the primary factor controlling algal biomass, and while there were significant effects of herbivory, they were insufficient to compensate for increased biomass in cleared areas (Figs. 2 and 4). To isolate the effects of light on algal growth in the presence of fish herbivory, we reanalyzed results from the herbivore exclusion experiment to include only cage controls and open sections of line. We found significant effects of treatment (cleared or intact mangroves), cage type (open or cage control), and their interaction, on algal biomass. Algal biomass is approximately equal in cage controls in cleared mangroves, where some shading occurs, and open lines in intact mangroves; biomass is highest on open lines in cleared mangroves, where light levels are highest, and biomass is lowest in cage controls in intact mangroves, where shading is doubled.
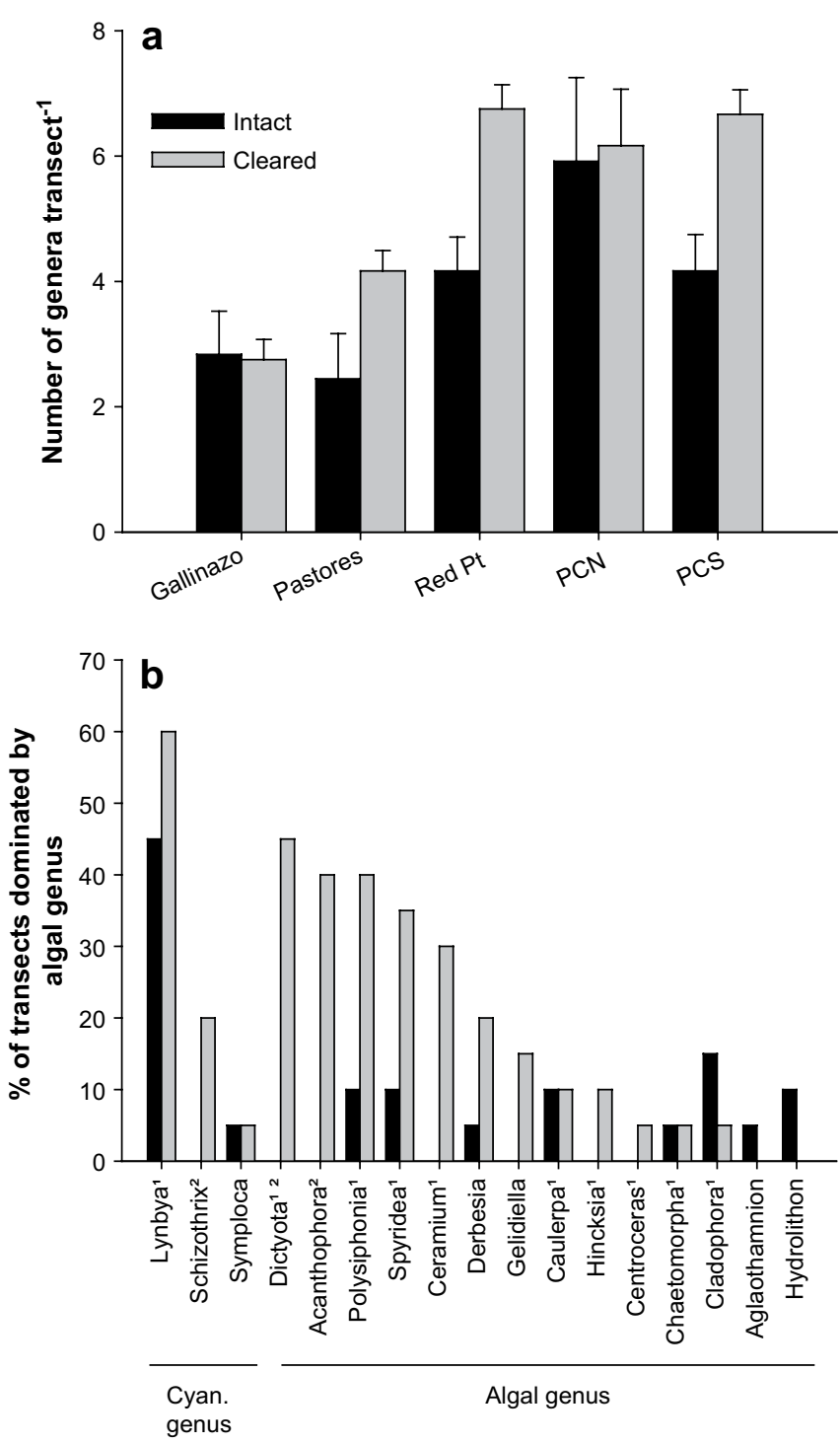

Fig. 3. (a) Mean number of genera per transect, by site and treatment. Error bars represent \pm 1 SE. (b) Percent of transects on which cyanobacterial or algal genus occurred along $>50 \%$ of the segment, by cleared and intact mangroves. Numbers next to genera indicate whether that genus has been observed overgrowing coral in other studies (1) (McClanahan et al. 2002; McCook et al. 2001), or overgrowing adjacent reefs in Panama during this study (2).

Mangrove-cleared areas had higher algal generic richness relative to mangrove-intact areas (Fig. 3a). Diversity and dominance of cyanobacteria (e.g., Lyngbya sp., Symploca sp., and Schizothrix sp.) and a variety of red, green and brown macroalgal taxa uncommon in local mangrove habitat were consistently higher in disturbed mangroves, and though cyanobacterial mats occur naturally in mangrove habitat (Joye and Lee, 2004), macroalgal growth was generally low in the undisturbed mangrove systems in this study. These findings suggest that algal and cyanobacterial growth conditions are much more favorable in mangrove-cleared areas due to increases in light availability. Similarly, experimental removal of vegetation in salt marshes led to significant shifts in species composition in both primary producer and faunal communities, even if species richness remained more or less constant (Whitcraft and Levin, 2007). These results demonstrate indirect biotic effects following removal of dominant vegetation, suggesting that human disturbance in aquatic habitats may have varying effects on biotic communities across ecosystems. 


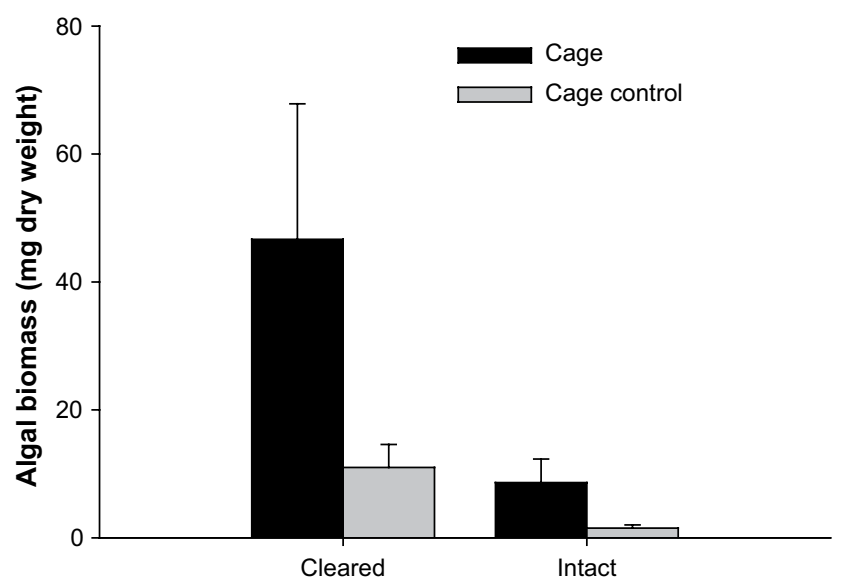

Fig. 4. Mean algal biomass in caging experiments, by treatment and cage/cage control. Error bars represent $\pm 1 \mathrm{SE}$.

Changes in algal community structure caused by mangrove clearing also have the potential to influence adjacent habitats, such as coral reefs. The algal genera dominating line segments in cleared areas were different than in intact mangroves, and included Acanthophora, Centroceras, Ceramium, Dictyota, Hincksia, Polysiphonia and Spyridea, some of which have been recorded on mangrove prop roots (Farnsworth and Ellison, 1996; Littler et al., 2000). Other studies have recorded these genera growing on coral reefs in Belize and competing with corals for light and space (McCook et al., 2001; McClanahan et al., 2002). By increasing algal biomass, facilitating algal compositional shifts, mangrove deforestation may indirectly facilitate algal growth on nearby patch reefs. Field observations indicate that Dictyota sp., Acanthophora sp., and cyanobacteria were overgrowing live and dead coral on Porites patch reefs adjacent to mangrove-cleared areas at Punta Caracole South and Red Point (E. Granek, unpublished data), and Dictyota and Acanthophora were two of the most dominant genera in cleared mangrove areas but were not present in intact mangrove areas (Fig. 3b). In addition, a survey of the literature showed that macroalgal genera found in mangrove-cleared areas in this study were coral competitors at other Caribbean locations (McCook et al., 2001; McClanahan et al., 2002).

There was no effect of clearing on sedimentation rates, but there were strong site and site $\times$ treatment effects. Part of this may be a function of different sedimentation processes in historically vs. recently cleared sites; sedimentation rates were generally greater in intact mangroves at historically cleared sites but higher in cleared mangroves at recently cleared sites. To further complicate this issue, there may also be changes in sedimentation rates due to loss of substrate as a result of clearing (e.g. Furukawa and Wolanski, 2004; Alongi and de Carvalho, 2008), but because this study occurred over a relatively short time period we were unable to measure changes in absolute substrate elevation.

While the pattern in total sedimentation rates was unclear, the organic content of the sediment sampled was significantly greater in intact than cleared mangroves. This difference is likely the result of two factors, either independently or in combination: (1) higher overall production of organic matter in intact mangroves and/or (2) greater trapping of organic particles in mangrove habitat. Whatever the mechanism, higher organic content may fuel detritivore communities in mangrove systems; the high productivity of these communities may decline as organic content of the sediments decline when mangroves are cleared, with subsequent shifts in these communities and of predators that depend on them. If mangrove-derived nutrients are indeed important to adjacent marine habitats (Jennerjahn and Ittekkot, 2002; Dittmar et al., 2006), loss of mangroves may result in reduced organic matter export to adjacent systems such as seagrass beds. If, on the other hand, mangroves are primarily responsible for greater trapping of nutrients, mangrove loss may inhibit the filtration of nutrients that could end up in adjacent systems including seagrass beds and reefs.

Finally, there was a great deal of site to site variability in many of the responses we measured, including a number of significant site terms and interactions that included site (e.g. site $\times$ treatment,
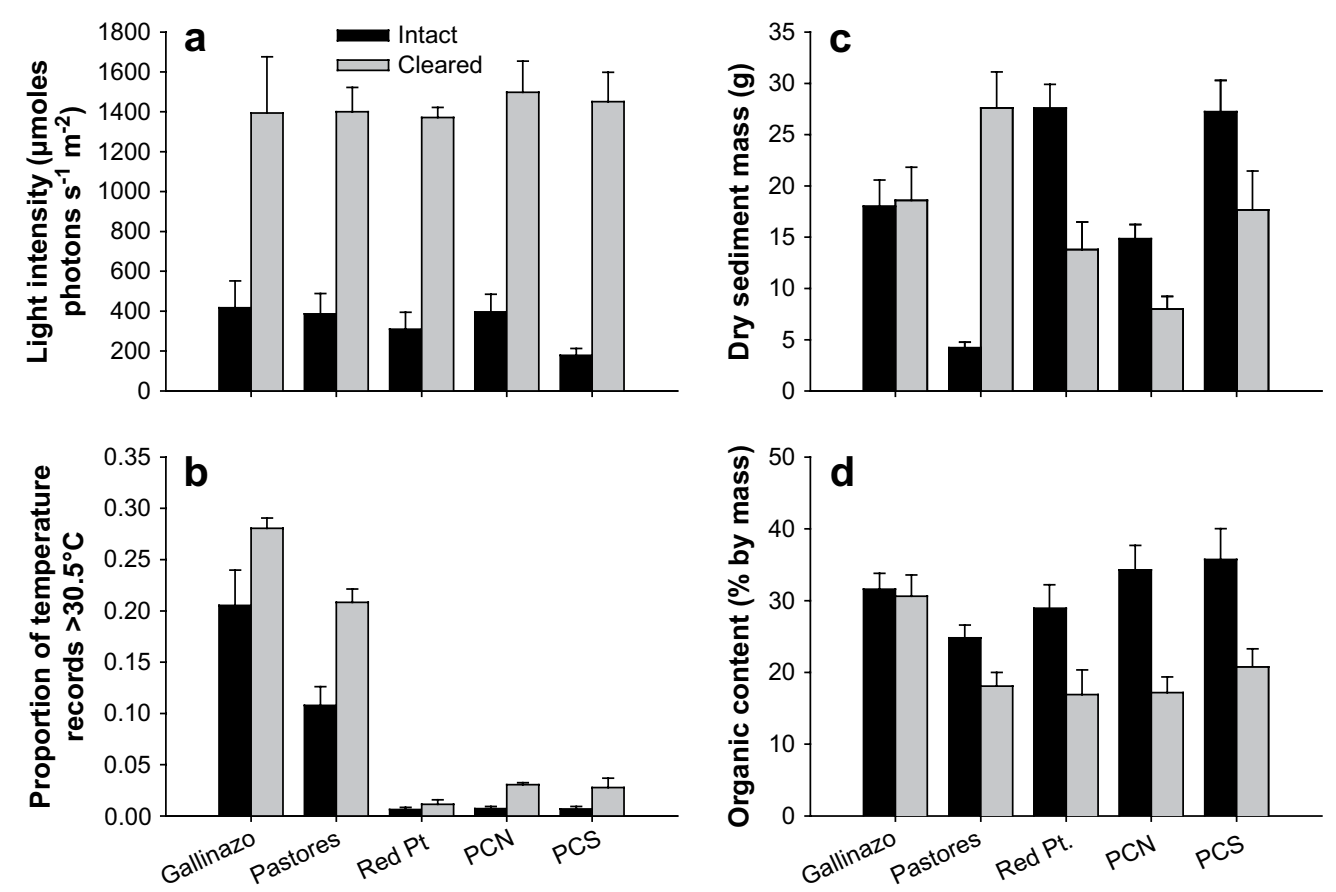

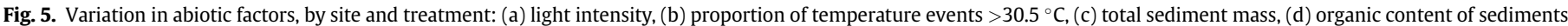
(\% by mass). Error bars represent \pm 1 SE for all plots. 
site $\times$ habitat) in the statistical models (Table 1 ). A number of factors could explain this variability. Two of the sites were recently cleared of mangroves (Pastores and Gallinazo), while the others were cleared $>8$ years ago. Our data suggest that some responses may have varied by age of clearing (e.g. Figs. 2 and 3a). Unfortunately we were unable to explicitly evaluate the effects of age of clearing because of small sample size. Other site-specific characteristics, such as stand age, water flow and depth might also influence the magnitude of biotic and abiotic responses at different sites, but we have no data on how these other factors may vary by site.

In this study, disturbance to ecosystem dominants, mangroves, led to changes in some abiotic factors, including light intensity and temperature, and biotic factors, such as organic content of sediments, ultimately influencing biological communities by increasing algal and cyanobacterial abundance and diversity. While many studies have suggested that mangroves are important for maintaining ecosystem processes in tropical coastal areas (e.g. RiveraMonroy and Twilley, 1996; Valiela et al., 2001; Chong, 2005; Ferwerda et al., 2007), our results demonstrate changes in a variety of abiotic and biotic factors as a result of mangrove clearing. Other work has suggested that mangroves may have strong influences on ecosystem processes in connected habitats, such as coral reefs and seagrass beds (e.g. Odum and Heald, 1972; Ogden, 1988; Hemminga et al., 1994; Mumby et al., 2004). Our findings indicate that even small scale clearing of mangroves can lead to significant changes in the physical and biotic conditions of the local environment, and highlight the need to consider mangrove conservation as a facet of more general marine management in tropical coastal systems.

\section{Acknowledgements}

We thank Bruce Menge, Jana Compton, Jane Lubchenco, Maria Kavanaugh, Rachel Collin, Eric Seabloom, Francis Chan, Roly Russell, Anne Guerry, Joe Tyburczy and Chris Krenz for assistance with experiment design, sampling and analysis methods. This research would not have been possible without the field assistance of Kaitlin Frasier and Nick Ehlers. Thanks also to Mark Brown, Alexandra Amat, Sea McKeon and the STRI Bocas del Toro staff for ideas and logistical support. This manuscript was significantly improved by comments from Sally Hacker, Eric Seabloom, Bruce Menge, Jane Lubchenco, Elizabeth Borer, Jana Compton and Chris Stallings. Funding from a Fulbright Fellowship, an NSF-GRF, The David and Lucile Packard Foundation, and a Smithsonian Tropical Research Institution - Supplemental Research Award made this research possible.

\section{References}

Alongi, D.M., 2008. Mangrove forests: resilience, protection from tsunamis, and responses to global climate change. Estuarine. Coastal and Shelf Science 76, $1-13$.

Alongi, D.M., de Carvalho, N.A., 2008. The effect of small-scale logging on stand characteristics and soil biogeochemistry in mangrove forests of Timor Leste. Forest Ecology and Management 255, 1359-1366.

Bothner, M.H., Reynolds, R.L., Casso, M.A., Storlazzi, C.D., Field, M.E., 2006. Quantity, composition, and source of sediment collected in sediment traps along the fringing coral reef off Molokai, Hawaii. Marine Pollution Bulletin 52, 1034-1047.

Brown, B.E., 1997. Coral bleaching: causes and consequences. Coral Reefs 16, S129-S138.

Buck, B.H., Buchholz, C.M., 2004. The offshore-ring: a new system design for the open ocean aquaculture of macroalgae. Journal of Applied Phycology 16, 355-368.

Butler, J.L., Bottomley, P.J., Griffith, S.M., Myrold, D.D., 2004. Distribution and turnover of recently fixed photosynthate in ryegrass rhizospheres. Soil Biology \& Biochemistry 36, 371-382.

Chong, J., 2005. Protective Values of Mangrove and Coral Ecosystems: a Review of Methods and Evidence. IUCN, Gland, Switzerland.

Dahdouh-Guebas, F., Jayatissa, L.P., Di Nitto, D., Bosire, J.O., Lo Seen, D., Koedam, N., 2005. How effective were mangroves as a defence against the recent tsunami? Current Biology 15, 1337-1338.
Dittmar, T., Hertkorn, N., Kattner, G., Lara, R.J., 2006. Mangroves, a major source of dissolved organic carbon to the oceans. Global Biogeochemistry Cycles 20, GB1012.1-GB1012.7. doi:10.1029/2005GB002570.

Dominici-Arosemena, A., Wolff, M., 2005. Reef fish community structure in Bocas del Toro (Caribbean, Panama): gradients in habitat complexity and exposure. Caribbean Journal of Science 41, 613-637.

Dye, A.H., 2006. Persistent effects of physical disturbance on meiobenthos in mangrove sediments. Marine Environmental Research 62, 341-355.

Eston, V.R., Braga, M.R.A., Cordeiromarino, M., Fujii, M.T., Yokoya, N.S., 1992. Macroalgal colonization patterns on artificial substrates inside southeastern Brazilian mangroves. Aquatic Botany 42, 315-325.

Farnsworth, E.J., Ellison, A.M., 1996. Scale-dependent spatial and temporal variability in biogeography of mangrove root epibiont communities. Ecological Monographs 66, 45-66.

Ferwerda, J.G., Ketner, P., McGuinness, K.A., 2007. Differences in regeneration between hurricane damaged and clear-cut mangrove stands 25 years after clearing. Hydrobiologia 591, 35-45.

Field, C.B., Osborn, J.G., Hoffmann, L.L., Polsenberg, J.F., Ackerly, D.D., Berry, J.A., Bjorkman, O., Held, Z., Matson, P.A., Mooney, H.A., 1998. Mangrove biodiversity and ecosystem function. Global Ecology and Biogeography Letters 7, 3-14.

Furukawa, K., Wolanski, E., 2004. Sedimentation in mangrove forests. Mangroves and Salt Marshes 1, 3-10.

Granek, E.F., Frasier, K., 2007. The impacts of red mangrove (Rhizophora mangle) deforestation on zooplankton communities in Bocas del Toro, Panama. Bulletin of Marine Science 80, 905-914.

Granek, E.F., Ruttenberg, B.I., 2007. Protective capacity of mangroves during tropical storms: a case study from 'Wilma' and 'Gamma' in Belize. Marine EcologyProgress Series 343, 101-105.

Gwyther, J., Fairweather, P.G., 2002. Colonisation by epibionts and meiofauna of real and mimic pneumatophores in a cool temperate mangrove habitat. Marine Ecology Progress Series 229, 137-149.

Hargrave, B.T., Burns, N.M., 1979. Assessment of sediment trap collection efficiency. Limnology and Oceanography 24, 1124-1136.

Hemminga, M.A., Slim, F.J., Kazungu, J., Ganssen, G.M., Nieuwenhuize, J., Kruyt, N.M., 1994. Carbon outwelling from a mangrove forest with adjacent seagrass beds and coral reefs (Gazi Bay, Kenya). Marine Ecology Progress Series 106, 291-301.

Hoegh-Goldberg, O., Salvat, B., 1995. Periodic mass-bleaching and elevated sea temperatures: bleaching of outer reef slope communities in Moorea, French Polynesia. Marine Ecology Progress Series 121, 181-190.

Hughes, T.P., Bellwood, D.R., Folke, C., Steneck, R.S., Wilson, J., 2005. New paradigms for supporting the resilience of marine ecosystems. Trends in Ecology \& Evolution 20, 380-386.

Irving, A.D., Connell, S.D., 2002. Interactive effects of sedimentation and microtopography on the abundance of subtidal turf-forming algae. Phycologia 41, 517-522.

Jennerjahn, T.C., Ittekkot, V., 2002. Relevance of mangroves for the production and deposition of organic matter along tropical continental margins. Naturwissenschaften $89,23-30$.

Joye, S.B., Lee, R.Y., 2004. Benthic microbial mats: important sources of fixed nitrogen and carbon to the Twin Cays, Belize ecosystem. Atoll Research Bulletin 528, 1-24.

Kelaher, B.P., Chapman, M.G., Underwood, A.J., 1998. Changes in benthic assemblages near boardwalks in temperate urban mangrove forests. Journal of Experimental Marine Biology and Ecology 228, 291-307.

Levin, L.A., Neira, C., Grosholz, E.D., 2006. Invasive cordgrass modifies wetland trophic function. Ecology 87, 419-432.

Littler, D.S., Littler, M.M., 2000. Caribbean Reef Plants. OffShore Graphics, Inc., Washington, DC.

Littler, D.S., Littler, M.M., Brooks, B.L., 2000. Checklist of marine algae and seagrasses from the ponds of the Pelican Cays, Belize. Atoll Research Bulletin 474, 153-206.

McClanahan, T.R., Cokos, B.A., Sala, E., 2002. Algal growth and species composition under experimental control of herbivory, phosphorus and coral abundance in Glovers Reef, Belize. Marine Pollution Bulletin 44, 441-451.

McCook, L.J., Jompa, J., Diaz-Pulido, G., 2001. Competition between corals and algae on coral reefs: a review of evidence and mechanisms. Coral Reefs 19, 400-417.

Mumby, P.J., Edwards, A.J., Arias-Gonzalez, J.E., Lindeman, K.C., Blackwell, P.G., Gall, A., Gorczynska, M.I., Harborne, A.R., Pescod, C.L., Renken, H., Wabnitz, C.C.C., Llewellyn, G., 2004. Mangroves enhance the biomass of coral reef fish communities in the Caribbean. Nature 427, 533-536.

Nagelkerken, I., van der Velde, G., Gorissen, M.W., Meijer, G.J., van't Hof, T., den Hartog, C., 2000. Importance of mangroves, seagrass beds and the shallow coral reef as a nursery for important coral reef fishes, using a visual census technique. Estuarine. Coastal and Shelf Science 51, 31-44.

Nagelkerken, I., Kleijnen, S., Klop, T., van den Brand, R., de la Moriniere, E.C., van der Velde, G., 2001. Dependence of Caribbean reef fishes on mangroves and seagrass beds as nursery habitats: a comparison of fish faunas between bays with and without mangroves/seagrass beds. Marine Ecology Progress Series 214, 225-235.

Naylor, R., Drew, M., 1998. Valuing mangrove resources in Kosrae, Micronesia. Environment and Development Economics 3, 471-490.

Nelson, D.W., Sommers, L.E., 1996. Total carbon, organic carbon, and organic matter. In: Sparks, D.A. (Ed.), Methods of Soil Analysis. Part 3: Chemical Methods. Soil Science Society of America, Madison, WI, pp. 961-1010.

Odum, W.E., Heald, E.J., 1972. Trophic analyses of an estuarine mangrove community. Bulletin of Marine Science 22, 671-738. 
Ogden, J.C., 1988. The influence of adjacent systems on the structure and function of coral reefs. Proceedings of the 6th International Coral Reef Symposium 1,123-129.

Ogden, J.C., 2001. Maintaining diversity in the oceans - issues for the new US administration. Environment 43, 28-37.

Pang, S.J., Luning, K., 2004. Tank cultivation of the red alga Palmaria palmata: effects of intermittent light on growth rate, yield and growth kinetics. Journal of Applied Phycology 16, 93-99.

Power, M.E., Tilman, D., Estes, J.A., Menge, B.A., Bond, W.J., Mills, L.S., Daily, G., Castilla, J.C., Lubchenco, J., Paine, R.T., 1996. Challenges in the quest for keystones. Bioscience 46, 609-620.

Rivera-Monroy, V.H., Twilley, R.R., 1996. The relative role of denitrification and immobilization in the fate of inorganic nitrogen in mangrove sediments (Terminos Lagoon, Mexico). Limnology and Oceanography 41 284-296.

Steneck, R.S., Dethier, M.N., 1994. A functional-group approach to the structure of algal-dominated communities. Oikos 69, 476-498.

Valiela, I., Bowen, J.L., York, J.K., 2001. Mangrove forests: one of the world's threatened major tropical environments. Bioscience 51, 807-815.

Walters, B.B., 2005. Ecological effects of small-scale cutting of Philippine mangrove forests. Forest Ecology and Management 206, 331-348.

Whitcraft, C.R., Levin, L.A., 2007. Regulation of benthic algal and animal communities by salt marsh plants: impact of shading. Ecology 88, 904-917.

Wilkie, M.L., Fortuna, S., 2003. Status and Trends in Mangrove Area Extent Worldwide. Forest Resources Assessment Working Paper No. 63. FAO, Rome. 